\title{
REVIVING A FAILED STATE \\ The 2005 General Elections in Liberia
}

\author{
Said Adejumobi PhD
}

\author{
Dr Said Adejumobi is Political Governance Adviser, \\ Economic Community of West African States (Ecowas) \\ 60 Asokoro District, Abuja, Nigeria \\ Tel: 234-8033482124 \\ e-mail: adesaid@yahoo.com \\ sadejum@cddnig.org
}

\begin{abstract}
The paper reviews the 2005 general election in Liberia, analysing its background, context, processes, dynamics, contradictions and outcomes. The election was generally acclaimed as the most competitive, free, fair, transparent, and credible in the political history of the country and constitutes a significant milestone in the transition from war to peace and the return to political normalcy and democratic rule. However, it evokes a curious paradox: how did a country just emerging from the ashes of a brutal war and unimaginable human destruction, aptly described as the quintessence of a failed state, manage to organise a credible and successful election? Postconflict countries are usually characterised by deep social and political divisions, low political consensus and immense organisational and logistical challenges in the conduct of elections. Three factors, both domestic and international, coalesced to facilitate the emergence of consociational electoral politics and the conduct of successful elections in 2005 in Liberia. These were: the fact that the Liberian people, exhausted by war and violence, were determined to try the electoral option in addressing the question of political power; the preparedness of the electoral commission, in spite of huge operational problems, to conduct free and fair elections; and the tremendous support for and commitment of the international community, especially the United Nations, the Economic Community of West African States, the African Union, and the European Union to the electoral process in Liberia. The successful election marked a process of political renewal and democratic rebirth for a beleaguered, war-ravaged nation.
\end{abstract}




\section{INTRODUCTION}

Liberia's political economy and historical trajectory present several paradoxes. First, the country is Africa's oldest republic. It came into being (as a sovereign state) in 1847 , yet it is a country that was aptly described by Rena Scott $(2005, \mathrm{p} 1)$ as the quintessence of a failed state. The country has recorded neither economic growth, democracy (which is just being revived) nor development. Public infrastructure has totally collapsed.

Second, it is a small country (estimated at about three million people) yet it fought one of the deadliest wars in Africa's history; a war in which no fewer than 200000 people were killed and whose brutality can only be ranked with the genocide in Rwanda.

Third, but quite interestingly, though it emerged from the ruins of war and anarchy Liberia set a precedent for the effective organisation and management of elections in West Africa.

Elections in post-conflict societies are frequently riddled with crises, conflicts and controversies. This is the result of a host of factors. The logistical challenges in organising elections in war-torn countries with poor facilities and networks and deep political discord among hitherto conflicting parties make both the management of elections and the securing of political consensus over their results very problematic. However, in Liberia this was not the case. The October general election and the run-off presidential election of November 2005 were generally adjudged by most local and international election observer groups to have been free, fair, transparent, and credible.

The fourth paradox is that, in a largely patriarchal African society where women are mostly apolitical and confined to the domestic arena, Liberia defied gender boundaries and stereotypes and elected the first woman president in Africa, Ms Ellen Johnson-Sirleaf.

These paradoxes therefore call for a thorough intellectual interrogation of Liberia's recent political trajectory and electoral experiences. How did Africa's oldest republic dissolve into war? How was the transition from war to peace negotiated? How was the electoral process consummated? How did the logic of consociational electoral politics prevail in Liberia? What are the prospects of and challenges to electoral democracy and democratic stability?

In this paper I argue that three factors are central to the emergence of consociational electoral politics and the success of the 2005 general elections in Liberia. First is the fatigue of war and violence and its fruitless dividends, which engendered a new determination among the Liberian people to make a success of the democratic option. Political restraint, accommodation and maturity characterised the conduct of both the political elite and the electorate before, during 
and after the elections. Second, is the international support for the elections and the preparedness of the electoral commission. The United Nations Mission in Liberia (UNMIL), Ecowas, the European Union (EU), the United States of America (USA), and private foundations and organisations like the International Foundation for Electoral Systems (IFES), the National Democratic Institute (NDI), and the Carter Center were committed to and fully supported the electoral commission. The third factor was the strategy of quiet diplomacy adopted by Ecowas in brokering peace and resolving post-election disputes.

The run-off elections precipitated tensions occasioned by allegations by the Congress for Democratic Change (CDC) led by George Weah of election rigging by the Unity Party. The actions of Ecowas, and especially its Special Mediator in Liberia, General Abdulsalam Abubakar, Nigeria's former head of state, were crucial to facilitating post-election consensus among all parties and the acceptance of the election results by the defeated presidential candidate, George Weah.

\section{CONFLICT, WAR AND STATE COLLAPSE}

In December 1989 Liberia, which had tottered on the brink of a fragile peace, finally but gradually dissolved into war. Some rag-tag soldiers under the banner of the National Patriotic Front of Liberia (NPFL), led by Charles Taylor, who had crossed into the country from Côte D'Ivoire, spearheaded the rebellion. The war was to last for an initial period of eight years (1989-1997), with an interregnum of about three years, but by 2000 Liberia had again relapsed into war. Liberia's civil war was one of the most gruesome and deadly wars fought in Africa. Apart from the human casualties, the notion of child soldiers, hitherto almost unknown in Africa, became part of the mechanisms of warfare. Sierra Leone was to take a cue from the Liberian tragedy.

There have been various attempts to explain the Liberian civil war (Osaghae 1996; Ellis 1995, 1998; Jarret 1996; Conteh, Guannu, Badio \& Bruce 1999; Adebajo 1989; Sesay 1992; Mgbeoji 2003; Aning 1997; Gershoni 1997; Hoffman 2004; Adejumobi 2004; Scott 2005; Gberie 2005). Economic rationality embedded in the 'greed-grievance' theory, the ethnic factor theory, the neo-patrimonial argument, and the bad governance thesis are some of the variables used in analysing the background to the war and the factors that precipitated it. Suffice it to say that no single explanatory model captures comprehensively the twists and turns of events in Liberia which led the country inexorably into war.

There are two levels at which the origins of the Liberian civil war can be analysed. The first is the genealogy and construction of the state system in Liberia; the second is the nature of political power and its management. 
Liberia, though established as the 'land of the free', was, in fact, the land of the unequal. From its inception the national creed of the country, its motto, 'The Love of Liberty Brought Us Here', was a statement of social distinction and hegemony. It is a motto that explicitly appropriates the Liberian state for the settler population, generally referred to as the Americo-Liberians, in denial of the existence and rights of the local indigenous African population that inhabited the territory long before the incursion of the settlers.

The creation of Liberia in 1822 was prompted by the need of the American Colonization Society (ACS) to resettle the freed black slaves from the USA. The group referred to as Americo-Liberians is not monolithic; it consists of three sets of settler categories. The first are the mulattos, who, as Osaghae $(1996, \mathrm{p} 6)$ notes, were free-born American citizens who occupied the lower rungs of the social ladder in the southern US in the early 19th century and who were lured to Liberia by the promise of a better and more comfortable life. The second group is the freed black slaves whose continued stay in the US was deemed threatening to the social and political fabric of American society and who were encouraged or cajoled to move to the new settlement. The third group consisted of recaptured slaves who were rescued from slave ships by the American navy. Through intermarriage and similar lifestyles the three groups crystallised into one social category referred to as Americo-Liberians.

The other social category is the native population, made up of about 16 ethnic groups bound together by domination. Between 1847 and 1904 only the AmericoLiberians enjoyed citizenship rights, the natives were considered subjects. Citizenship was only extended to the locals in 1904. However, the structure of domination and social exclusion remained unchanged. As Conteh et al (1999, p 113) note, 'Between 1904 and 1980, the portions of the organic law, a number of national symbols and the values of the Liberian political system were still dysfunctional to the creation of a common national identity and of necessity, to the native's meaningful participation in the distribution of decision making.' For example, it was not until 1946 that the provinces had any representation in the national legislature.

The natives were also victims of heavy taxation, forced labour, land dispossession and general discrimination. The indirect rule policy adopted in 1906 effectively consolidated the policy of exclusion and domination akin to what Mahmood Mamdani (1996) described in the South African context as 'decentralized despotism'. The natives were locked into 'tribal' administrative areas governed by their chiefs and traditional authorities, thereby almost exclusively cut off from national or central administration and politics. The major relationship of the chiefs to the capital (Monrovia) was paying taxes and providing forced labour for the central authority. 
The dualism of power and laws that characterised the Liberian political system has been aptly described by Abiodun Alao et al (1999, p 12) as 'democratic feudalism' and, more appropriately, by Eghosa Osaghae (1996, p 23), as 'internal colonialism'. The Americo-Liberians, as Osaghae qualifies them, constitute an 'ethclass', an ethnic or social category which, in a sense, is also a class category. This group controls not only political power but the economic resources of the country.

The 'open door' policy of the Tubman administration (1944-1971) conceded some political and social space to the natives while, at the same time, further liberalising the economy to foreign capital. Educational opportunities for the natives increased, some infrastructural facilities were put in place, and the level of participation was slightly enhanced. However, the concessions did not include meaningful political rights. All attempts by the indigenous people to engage the political system were rebuffed by the political oligarchy and met with stiff repression. ${ }^{1}$

The irony of Tubman's liberalisation policy was that it afforded the indigenous people access to education, which they were later to use to agitate for political rights and inclusion. Alao, Mackinlay \& Olonisakin (1999, p 17) put it poignantly:

Ironically, it was Tubman's educational policies that acted as catalyst for political change. His foreign scholarship programme provided the opportunity for many Liberians to study abroad. This broadened their knowledge and understanding and they began to question Liberian laws and their government. These scholars will later form groups that would bring serious pressure to bear on the government of the settlers.

By 1971, when Tolbert took over power after the death of Tubman, opposition forces had become fairly well organised and the level of resistance had risen. Both democratic and violent options were palpable in the political calculations of the indigenous people. Civil opposition groups sprang up both at home and in the diaspora. They included the student movement based at the University of Liberia, the Movement for Justice in Africa (Moja), the Progressive Alliance of Liberia (PAL), and the Union of Liberian Associations in America. The rice riots

\footnotetext{
Osaghae (1996, p 53) documents two cases of the denial of attempts by the local people to contest for the presidency. In 1931 the name of Momolu Massaquoi, an assimilated native who had previously held diplomatic positions, was erased from all documentation because he dared to declare an interest in contesting the presidential elections. In 1951 Didwho Twe Kru was similarly frustrated.
} 
of April 1979, ${ }^{2}$ which were spearheaded by students and actively supported by radical lecturers who were members of Pal, provided the context for the fall of the Tolbert regime.

On 12 April 198017 indigenous subaltern officers of the Liberian Armed Forces (LAF), led by Sergeant Samuel Doe, staged a military coup, putting paid to Americo-Liberian hegemony in the politics of Liberia. Identity and citizenship factors provided a context for the coup. As Stephen Ellis (1998, p 167) notes, 'Doe and those who took over with him in 1980 were broadly typical of a generation of young men who had entered the army with certain expectations, and found their path to promotion blocked by an officer corps dominated by Americo-Liberian families.' However, and quite expectedly, the young coup plotters, as Max Bankole Jarret (1996, p 9) correctly observes, were united in purpose but not in vision.

What followed was a reign of brutality, terror and repression. Initially Doe assembled a popular coalition team made up of the opposition democratic forces but, a few years into his regime, he had removed all of them and executed all the subaltern officers with whom he had planned the 1980 coup. It appears that political insecurity, fuelled by incompetence, was a major factor in Doe's descent into political tyranny. In 1985 Doe organised sham elections through which he transformed himself into a civilian president. He ruthlessly consolidated political power and furthered the mechanisms of personal rule, which previous regimes in Liberia had constructed and strategically maintained. The possibilities for nonviolent political change were increasingly foreclosed as Doe's dictatorship intensified. Both exiled political forces and domestic ones began to organise for regime change, a process which, inevitably, led to the December 1989 insurgency by the NPFL.

What are the salient factors in Liberia's political economy that fuelled the crystallisation of the war? The first is the notion of highly centralised political power and the phenomenon of personal rule embedded in the presidency. The presidency provides a ready attraction for elite competition and keen political struggles. Jarret (1986, p 21) avers:

the ultimate prize for the faction leaders and their clientelist network is the presidency which given the centralized nature of Liberian political economy provides the greatest opportunities for amassing wealth and power. The presidency is also a political resource in itself as it can be used to coerce opponents and to extract substantial

The rice riots were precipitated by the increase in the price of a bag of rice from $\$ 22$ to $\$ 30$ in April 1979. Rice is a staple food in Liberia. 
financial resources from the economy needed to fund a patronage network over the long term. It also has the essential benefit of providing status and international recognition which all the so called 'warlords' crave.

This explains why there were many splinter groups among the rebel movements after the war broke out, each of them wanting to control territory and resources.

The second element is the nature of Liberia's economy and state revenue base. The economy is rentier in nature, with foreign capital paying rent, solely appropriated by the leadership, for the extraction of natural resources including timber, rubber and wood. This situation creates power without responsibility and leadership devoid of accountability. Many of the resource extraction contracts entered into by successive governments were dubious and intended to facilitate the personal interests of the leadership as well as their hold on the economy. For example, Firestone Rubber and Tire Company, an American firm, was granted a 99-year lease on a plantation farm for $\$ 1$ an acre for the first year and a flat $\$ 6000$ per year rent thereafter (Pham 2004, p 39) - a contract which, like many others of its kind, was very controversial.

The trend continued even during the war when the 'warlords', especially Charles Taylor, 'mortgaged' the forest resources of the area under their control to foreign firms in return for cash to buy arms and wage the war. It is estimated that Taylor may have personally derived about \$75-m annually from such deals (Adebajo 1989, p 47). There is no doubt that a centralised rentier economy can be an incentive for deadly political contestation, especially where an indigenous capitalist class is virtually non-existent or too weak.

The third element in Liberia's civil war is the external political factor. Bad political leadership and governance were nurtured and subsidised by the USA under the guise of containing the spread of communism in Africa during the Cold War. In spite of the political failings of Samuel Doe, the US continued to pump money in and to provide military and security assistance to the regime. From a figure of about $\$ 20-\mathrm{m}$ in 1980, at the time of Doe's rise to power, US aid to Liberia increased to about $\$ 500-\mathrm{m}$. The US also provided training for Doe's troops, built barracks, and supplied uniforms, weapons and trucks (Alao, Mackinlay \& Olonisakin 1999, p 25; Massing 1990; Zimmerman 1993). However, by 1989, US support for Doe had waned as the Cold War receded. For instance, the United States Agency for International Development (USAID) closed its offices in Liberia in March 1989 and US aid dropped dramatically, which had a debilitating effect on the Liberian economy. As Jarret (1996, p 14) noted, 'by mid-1989, Samuel Doe was without the support of one ally that had propped him since 1980, and desperate. The national economy was disintegrating.' Indeed, some have 
suggested that the withdrawal of US support for Doe was a catalyst in the outbreak of the war.

The Liberian civil war, fought with more crudity, bestiality, and vengeance than could ever be imagined, resulted in the virtual collapse of the state. Public infrastructure - electricity, water supply, roads, schools, and public buildings especially in the capital city, Monrovia, were completely destroyed. At the height of the war, the 'warriors' were apparently angry with nature and trees and other natural resources became targets. As a Liberian observer noted, 'When there was no longer anyone to kill or shoot at sight the rebels under the influence of hard drugs, turned their anger to trees and other nature objects, firing sporadically at them. ${ }^{\prime 3}$ In the circumstances it is not surprising that the road to peace was to prove arduous.

\section{ROAD TO PEACE AND ELECTIONS}

Between 1990 and 1997 there were 13 major Ecowas-sponsored peace agreements, none of which could guarantee peace in the country (Scott 2005, p 37). Warring parties had no sooner signed peace agreements declaring a cessation of hostilities than they reneged on their implementation and relapse back into war. It was on 18 August 2003 in Accra, Ghana, that a more durable agreement, generally referred to as the Comprehensive Peace Agreement (CPA), was signed. There were four main parties to the agreement - the Government of Liberia (GOL) under Charles Taylor; the two main rebel movements, the Liberian United for Reconciliation and Democracy (Lurd) and the Movement for Democracy in Liberia (Model); and 18 political parties.

The CPA was an extra-constitutional framework acceded to by all the parties for the management of the political transition process in Liberia leading to general elections in 2005 . The agreement facilitated by Ecowas was guided by the Ecowas principles of democratic practice, respect for the rule of law and good governance as enshrined in the Ecowas Declaration of Political Principles of 1991, the Protocol Relating to the Mechanism for Conflict Prevention, Management, Resolution, Peace-Keeping and Security of 1999, and the Ecowas Supplementary Protocol on Democracy and Good Governance of 2001, to all of which Liberia acceded.

The CPA suspended important aspects of the Liberian Constitution and took precedence over it in cases of conflict. It provided for a transitional governmental structure, the National Transitional Government of Liberia (NTGL), and important institutions and agencies to facilitate political change and the transition process.

Interview conducted by the author with a Liberian informant in October 2005 during the general election in the country. 
The NTGL was made up of three organs: the executive, headed by a transitional chairman selected by consensus; the National Transitional Legislative Assembly (NTLA), and the judiciary. The two former organs consist mainly of nominees of the parties to the agreement. The NTGL was to perform the following functions, apart from its normal state functions:

a) Implement the Ceasefire Agreement.

b) Oversee and coordinate implementation of the political and rehabilitation programmes enunciated in the Peace Agreement.

c) Promote reconciliation to ensure the restoration of peace and stability to the country and its people.

d) Contribute to the preparation and conduct of internationally supervised elections in October 2005, for the inauguration of an elected Government for Liberia in January 2006 (Liberian Comprehensive Peace Agreement of 2003, Article XXII, 1 and 2).

The NTGL was inaugurated on 14 October 2003, led by Gyude Bryant, and was expected to expire on the third Monday of January 2006, when a new elected government would be installed.

Some other major components of the CPA include:

- Disarmament, demobilization, rehabilitation, and reintegration (CDDRR): This was intended to demilitarise the country, restore order and stability, and restore the militias to normal civil life.

- Security sector reform: This involves the restructuring of the armed forces of Liberia through the integration of the different forces, retraining them and ensuring balanced geographical representation. The USA was designated as a major partner in this reform. Other paramilitary forces like the police, immigration services and the special security services (SSS) were to be restructured to adopt a professional orientation and respect the democratic values of human rights, a non-partisan approach to their work, and avoidance of corruption.

- Respect for human rights and the rule of law: All the parties to the agreement, and the Liberian people generally under the CPA, were obliged to respect fundamental human rights and the rule of law as enshrined in international human rights instruments to which Liberia is a signatory, and the laws of Liberia. The basic civil and political rights include right to life and liberty, freedom 
from torture, the right to a fair trial, freedom of conscience, expression and association, and the right to take part in the governance of the country. In addition, an Independent National Commission on Human Rights (INCHR) was to be established.

- Establishment of a Governance Reform Commission: This commission was to be a vehicle for the promotion of good governance in Liberia through a review of the objectives, scope and strategies of existing programmes on good governance, undertaking public sector management reforms, and ensuring transparency and accountability in all government institutions.

- Electoral Reform: Under the CPA, the electoral system in Liberia was to be reformed. The reforms include: (i) the reconstitution and independence of the National Elections Commission (NEC), which is required to conform to UN standards in order to ensure that the rights and interests of all Liberians are guaranteed and to organise elections in a manner acceptable to all in Liberia; (ii) reform of the electoral law; (iii) re-demarcation of constituencies to take account of the newly created counties; (iv) seeking the support and cooperation of the UN, AU and Ecowas, and other members of the international community in the conduct, monitoring and supervision of the elections; $(\mathrm{v})$ ensuring that elections were conducted not later than October 2005.

These were the salient provisions of the CPA, especially as it related to governance and elections in the transitional period in Liberia. While the CPA has generally been applauded as a road to peace in Liberia, some argue that it perpetuates a culture of impunity with a flawed assumption that political power can be exchanged for military peace by allocating seats to rebels in the NTGL and granting them blanket amnesty. Scott (2005, pp 42-43) argues:

The possibility of general amnesty is one of the most serious flaws of the CPA. Besides the fact that the granting of a general amnesty is a diplomatic way of encouraging rebels to participate in the peace process, there are several theoretical and practical problems with this form of concession ... amnesty alone is a dangerous formula for peace because of the messages it sends to elites, to rebels, and to society that crimes can be committed and civil wars staged with no consequence for any of the parties involved. Finally, the blind granting of amnesty does not consider the moral hazards of dismissing the role of punishment of the main perpetrators. 
In summary, there are four criticisms of the CPA:

- It privileges amnesty over justice, which perpetuates a culture of impunity.

- It rewards crime and warlordism and perpetuates a culture of pillage and corruption.

- It marginalises and does not include the voices of the ordinary people in the negotiation process, making it an agreement of war belligerents and not the people.

- Negotiated settlements do not necessarily guarantee peace.

While these criticisms are logical, the CPA should be placed in its historical context. Liberia had succumbed to a cyclical process of war, and the state was virtually non-existent. The interests and considerations of the warring parties could not be neglected in the peace agreement.

International support and coalition was required to sustain the transitional government. The International Contact Group on Liberia (ICGL), its members the UN, Ecowas, the AU, the EU, Nigeria, Morocco, Ghana, Senegal, the USA, the UK, Germany, and France, was a major actor in the transition process, reviewing developments as they unfolded and advising the Liberian government and the UN on the way forward. UNMIL played a central role in the security and electoral processes of the country, while Ecowas was the major political broker and guarantor of the CPA. The Executive Secretary of Ecowas appointed and deployed a Special Representative to Liberia (Ansumana E Ceesay) and established an office there. Ecowas also appointed a Special Mediator for the Liberian peace process (General Abdulsalami Abubakar). The EU and the USA also played important roles in the country's political transition.

\section{PLANNING AND MANAGING THE ELECTORAL PROCESS}

The CPA provides the overarching framework for the electoral process in Liberia. As observed above the agreement required a reform of the electoral institution, the electoral law, the conduct of elections according to UN standards, and the elections to be conducted on or before October 2005.

A major step in the process was the reconstitution of the electoral commission. The name of the commission was changed from the Elections Commission to the National Elections Commission of Liberia (NEC). Article XVIII section 2B of the CPA stipulates that 'the appointment of the NEC shall be made by the Chairman with the advice and consent of the NTLA within three months from the entry into force of this Agreement. It shall be composed of men and women of integrity.' 
The chairman of the Transitional Government nominated seven commissioners, led by Ms Frances Johnson-Morris as chairperson, and the nominations were approved by the NTLA. The commission was inaugurated on 29 April.

The NEC is an autonomous oversight and policy-making body, responsible for overall supervision and control of the electoral process including the preparation, organisation, and adoption of measures to ensure the freedom and fairness of elections in Liberia. It is supported by an administrative electoral division comprising an executive director and staff. The division is responsible for all practical activities relating to the preparation and conduct of the electoral process and is organised at both national and county levels. A magistrate heads each county and sub-county electoral office and reports directly to the executive director of the division (UNMIL 'Electoral Division' http//www. Unmil.org/ elections).

The functions of the electoral commission include:

a) administering and enforcing all laws relating to the conduct of elections throughout Liberia;

b) proposing to the National Legislature for enactment, amendment to, and repeal of, any provision of the Electoral Law;

c) accrediting and registering all political parties that meet registration requirements as laid down by the commission;

d) conducting all elections for elective public office, including the chieftaincy election and all referenda, and declaring the results thereof;

e) formulating and enforcing guidelines for controlling the conduct of all elections for elective public office;

f) maintaining a register of qualified voters;

g) screening all candidates for elective public office and accrediting their candidacy and rejecting candidates not qualified under the guidelines laid down by the commission;

h) examining financial transactions and audited accounts of political parties;

i) handling election disputes, which may later be referred to the Supreme Court, as final arbiter;

j) Submitting an annual report to the national legislature and the president on the general operation of the commission. 
The electoral process consists of five distinct phases:

- Establishment of the National Elections Commission.

- Setting up the legal framework and defining the electoral system.

- Conducting operational activities in relation to the elections. These include:

(i) voter registration and display of voters' register;

(ii) registration of political parties;

(iii) allocation of seats and demarcation of electoral districts;

(iv) training of electoral officers;

(v) candidate nomination by political parties.

- Election Activities. These include:

(i) political campaigns;

(ii) polling;

(iii) counting votes, tallying them and announcing election results.

- Post election activities:

Petitions over election results and adjudication of election disputes.

The passage by the NTLA of the Electoral Reform Law in December 2004 marked an important step in the electoral process in Liberia. The law suspends certain provisions of the Constitution of Liberia and amends some sections of the New Elections Law of 1986. It also includes new provisions, especially that relating to budget appropriations by the NEC, which is a major factor in guaranteeing its autonomy. There are four sources of the legal instruments and legal framework of elections in Liberia: the 2004 Electoral Reform Law, the Liberian Constitution, the New Elections Law of 1986, and regulations and guidelines issued by the NEC.

The Electoral Reform Law covers the nature of the electoral system, eligibility to stand for public office, allocation of seats in the Senate and House of Representatives, registration of political parties, campaign finance, registration of voters, voting and vote counting, electoral offences, declaration of election results, and budget appropriation.

The law stipulates a majoritarian two-round electoral system for election to the office of president and vice-president. The first round is to be determined by an absolute majority ( $50 \%$ plus one) of the valid votes cast. If no candidate obtains an absolute majority in the first ballot, a second ballot is to be conducted on the Tuesday following the announcement of the first ballot. The two candidates who obtained the highest number of votes in the first ballot participate in the run-off elections. The candidate who obtains the majority of the valid votes in the second ballot is deemed to be elected. 
For the Senate and House of Representatives there is a simple majority electoral system. The two candidates who obtain the highest and second-highest number of valid votes cast in a county are deemed elected to the Senate. The senator with the highest number of votes is senator of the first category, while the second is senator of the second category.

A simple majority system governs elections for the House of Representatives, with single-member electoral districts, each of which consists of voting precincts designated by the NEC with the stipulation that they must be within a county boundary and contain not more than 2000 registered voters (Electoral Reform Law of Liberia 2004, s 5, (1p)).

The Electoral Law stipulates that the president and vice-president should not come from the same county, and suspends the ten-year residency clause in the Liberian Constitution that is a prerequisite for contesting elections. The law grants adult Liberians who are taxpayers in Liberia the right to contest the 2005 elections.

The Electoral Law, together with the Campaign Finance Regulation of July 2005 issued by the NEC, lays down stringent regulations about campaign financing, setting limits for campaign expenditure and prescribing guidelines for how campaign finances are to be managed and accounted for. For instance, for the president and vice-president election expenses may not be more than $\$ 2-\mathrm{m}$ and \$1-m respectively. For the Senate and House of Representatives, the limits are $\$ 600000$ and $\$ 400000$ respectively, while for any other elective office the expenditure level is pegged at $\$ 75000$. Political parties and candidates running for public office must constitute 'campaign committees' which have a treasurer, and maintain a bank account and receive all donations and funds for campaign purposes. The treasurer must record the details of all funds raised and all expenditure. Parties and individuals are prohibited from raising funds for campaigns from anonymous sources, corporations, labour unions and banks; from the abuse of state resources; non-citizens; or foreign governments. In practice, however, it has been difficult for the NEC to track and regulate party campaign finances.

An interesting element of the electoral law is the relative autonomy granted to the NEC on financial matters. Its funding is directly charged to the national revenue, and duly appropriated by the NTLA. However, in the interests of probity and accountability the NEC is required to have its accounts externally audited and publish an annual report, which includes detailed financial reporting.

With the legal framework for the electoral process established, preparations for the registration of voters by the NEC began in earnest. A voter registration task force was constituted, consisting of the NEC, UNMIL, IFES, and EC, which distributed its work to 12 working groups. Recruitment of voter registration personnel, logistics, and civic education on the registration exercise were all 
conducted at this phase. The NEC created 1511 registration centres with 1000 registration teams (staffed by about 4000 personnel) constituted to service the centres, with some of the teams being mobile. Civil society organisations (CSOs) such as the Christian Church, Women in Peace Building Network (WIPNET), the Coalition of Political Party Women in Liberia (COPPWIL), and the media were mobilised and participated actively in the exercise. Voter registration was conducted from 25 April to 21 May 2005. In all, the total number of registered voters was 1352730 , with slightly more women than men registering. The average age of registered voters was 35 and 35 per cent of those registered live in Montserrado County, where the capital city is located (Carter Center 2005a). In commending the success of the registration exercise the chairperson of the NEC, Frances Johnson-Morris (see the Ballot, 2005), observed:

The National Elections Commission (NEC) is extremely gratified by the strong will demonstrated by the Liberian people to bring this transition and all that it represents to an end. This was manifested by the impressive turnout by eligible Liberians to register from 25 April to 21 May 2005 despite all odds.... Of course without the moral, financial and material support of the National Transitional Government of Liberia (NTGL), the UNMIL, USAID/IFES, EC, Ecowas and AU, this effort would not have succeeded. Indeed, Liberians owe those partners a debt of gratitude.

The registration of political parties was conducted between April and June 2005. In all 25 parties and alliances/coalition groups were registered. They were the: True Whig Party (TWP), National Patriotic Party (NPP), National Democratic Party of Liberia (NDPL), Unity Party (UP), Free Democratic Party (FDP), All Liberia Coalition Party (ALCOP), Progressive People's Party (PPP), Labour Party of Liberia (LPL), Liberia Equal Rights Party (LERP), National Reformation Party (NRP), New Deal Movement (NDM), National Party of Liberia (NPL), Union of Liberian Democrats (ULD), Congress for Democratic Change (CDC), United Democratic Party (UDP), Liberty Party (LP), Reformed United Liberia Party (RULP), Freedom Alliance Party (FAP), National Vision Party (NAVITPOL), Liberia Destiny Party (LDP), Progressive Democratic Party (PRODEMP), Independent Democratic Party (IDP), Coalition for the Transformation of Liberia (COTOL), Alliance for Peace and Democracy (APD); United Democratic Alliance (UDA) . ${ }^{4}$

4 COTOL, the APD and the UDA are alliances and coalitions. COTOL comprises three parties: the Liberia Action Party, the Liberia Unification Party and the People's Democratic Party. The APD is made up of the United People's Party, and Liberia's Peoples Party, while the UDA is made up of the Liberia National Union, the Reformation Alliance Party and the Liberia Educational Development Party. 
The parties represent both the old political party lineages like the True Whig Party and the NPP, which have simply been resurrected, and relatively new parties, with new political actors on the political scene. The New Deal, led by George Klay Kieh, and the CDC, led by George Opong Weah, are new parties with new leadership. There are three categories of political actors - the old politicians like Togba-Nah Tipoteh, Ellen Johnson-Sirleaf, Charles Brumskine and Varney Sherman, who have participated in the governance and politics of Liberia for two decades or more; those who, in popular discourse, are referred to as the warlords - people who participated militarily in the civil war either leading armed groups or as foot soldiers; and the younger generation, who apparently desire genuine political change and therefore created new political platforms as the basis of new political identities.

However, some common features run through many of the parties, especially the prominent ones. Among these are the dominance of personalities, especially the founders of the party or their prospective presidential candidates, and reliance on funding from those individuals rather than from contributions from the party membership. Thus, the parties are susceptible to strong control by individuals and have weak organic roots in society.

Understandably, many of the parties lacked strong organisational networks because of the limited time available to establish these and to mobilise for the elections.

The nomination of candidates took place from 21 July to 6 August 2005. The process included some horse-trading, floor crossing and alliance formation based on the interests of the candidates and the possibility of using a winnable platform to contest the election. ${ }^{5}$ The presidential and vice-presidential nominations were won by many of the notable candidates who had been at the forefront of party activities. Essentially, however, most of the party primaries were characterised by democratic deficits. As The Analyst, a prominent Liberian newspaper, noted (17 May 2005, p 2):

The Modus Operandi of most political parties in selecting standard bearers for ensuing elections is a major democratic flaw in the bids for Liberia's presidency that most political analysts are pointing to as a troubling writing on the wall. Many political parties have now selected their standard bearers in party conventions that did not

\footnotetext{
For instance, there were some defections from the ranks of the NPP, with Nyan Matain, a former Minister of Commerce in Charles Taylor's government, leaving the party to join the Unity Party, led by Johnson-Sirleaf. John Witfield, the party's national secretary, and youth leader Edwin Snow left the party to run as independent candidates.
} 
feature opponents or where opponents were brushed aside as

'troublemakers' attempting to undermine the Godfather.

The party primaries or conventions were therefore, in most cases, regarded as a stage-managed exercise; a travesty of democratic politics.

A total of 779 candidates were nominated during party conventions -27 for president, 25 for vice-president, 206 for the Senate and 521 for the House of Representatives. When the lists were submitted to the NEC for scrutiny and approval 762 candidates were approved -22 presidential and vice-presidential, 206 for the Senate and 513 for the House of Representatives. Only 14 per cent of the nominees approved by the NEC were women. This was in contravention of the commission's directive that parties should nominate 30 per cent of women for general elections. Regrettably, the NEC did not enforce this regulation or impose sanctions for non-compliance or rewards for compliance.

\section{THE GENERAL ELECTION OF 11 OCTOBER 2005}

Activities leading up to the election included the training of polling officials, extensive civic education, and campaigning by political parties. In September 2005 the NEC commenced a rigorous training exercise involving 18000 polling officials all over the country. Earlier, NEC magistrates and UNMIL electoral officials had undergone a 'training of trainers' programme to facilitate the training of the field electoral officials. The NEC's mobilisation and sensitisation programme included organising cultural activities and workshops, establishing Civic Education County Committees, and employing the services of the media, especially the electronic media, in outreach to the remote parts of the country. Civil society organisations, international agencies, and political parties complemented the efforts of the NEC in this regard. The NEC created 1421 voting precincts with 3070 polling booths.

\section{Political campaigns}

Campaigning commenced on 15 August and ended at midnight on 9 October. Commendably, the parties adopted a 'Code of Conduct' committing themselves to play by the 'rules of the game' and expressing their determination to 'build lasting democratic self-governance for present and future generations of Liberians' as well as 'to the growth and development of responsible multi-party democracy, and to the decentralization of political power in our country in place of the authoritarian political power centre that generally contributed to the dysfunctional state system and governance' (Code of Conduct, p 5). 
The code stipulates that all parties must: abide by existing laws and regulations on political campaigns; not obstruct, disrupt or break up meetings, rallies or other activities of another party; desist from destroying, removing, defacing or in any way tampering with the posters, logos, symbols, handbills, or publicity material of another party; eschew violence - their members or supporters should not carry arms or any offensive weapons; and should, in good faith, coordinate their campaign activities so that no two parties would hold public meetings or rallies at the same venue or locality on the same day in order to avoid the possibility of conflict. In addition, an Inter-Party Coordination Committee was constituted to create a platform for dialogue among the political parties and with the NEC. Undoubtedly this was a clear commitment by the parties to consociational electoral politics and demonstrated that they were conscious of history and determined not to repeat the mistakes of the past.

Generally the political campaigns were full of festivities, glamour and understanding. The campaign methods adopted by the parties included houseto-house canvassing; the use of billboards, posters, banners and T-shirts; rallies; and messages and jingles on radio and television. Radio provides the most extensive outreach for electioneering given the challenges of the poor road infrastructure in the country. In order to ensure equal access of parties to media coverage and to encourage issue-based campaigning, the Press Union of Liberia (PUL) established an 'Elections Coverage Code of Conduct' for its members. The PUL Grievances and Ethics Committee was invigorated to hear cases of unfair media coverage.

The PUL insisted that political parties and independent candidates make their manifestos public or face the penalty of a media blackout. Most of the radio and television stations, including the state radio, were fair and professional in their coverage. The print media were more partisan because of the ownership interests of some of the candidates.

Civil society was also actively involved in ensuring a free and fair campaign, forming a coalition of CSOs, the Campaign Monitoring Coalition (CMC), to track the process. The group intervened at critical moments to draw attention to the unfair and illegal activities of some candidates and parties. For instance, there were allegations of vote-buying by candidates and some candidates deployed state resources such as vehicles and funds to support their campaign (The Inquirer 14 September 2005). The allegations were promptly investigated by the NEC, with the NTGL taking appropriate steps to correct the misuse of state facilities.

On 15 September the PUL organised a presidential debate with the NDI and the International Republican Institute (IRI). Eleven of the 22 presidential candidates participated. The debate was generally lively and friendly, but sometimes became confrontational, with candidates seeking to make political 
capital of the event. As one presidential candidate who participated, Joseph Korto of the Liberia Equal Right Party, rightly remarked, 'The greatest thing about this debate is to see Liberian presidential candidates sitting here and talking to each other and trying to convince voters rather than being in the bush and shooting at each other' (Dukule 2005). Beyond the political marketing of candidates and their programmes, the debate reinforced the spirit of consociational politics among the key political actors in the electoral process.

George Opong Weah, the CDC candidate, was the most generally popular of the 22 presidential aspirants. He commanded massive support from the youth, who saw him as a beacon of hope for young people who had been ignored by successive political leaders. Rather than detracting from his support base his poor educational qualifications attracted sympathy, with many of the uneducated youth and former child soldiers seeing in him the image of their own deprivation. His youthfulness and recent arrival in the political arena were also assets. The youth coined two campaign slogans on his behalf: 'Whether he go school or he no go school, we go vote for am' and 'Opong kill your mama, No! Opong kill your papa, No! Opong give you gun, No!'6

A political march held in Monrovia by Weah a few days before the election was attended by more than 500000 youths demonstrating total commitment to and passion for their 'idol'.

In summary, the political campaigns were conducted in an orderly, friendly and positive manner. As the European Union Election Monitoring Team observed (13 October 2005, p 5):

The election campaign was conducted in a positive atmosphere, with no reports of restrictions of freedoms of expression, assembly, and association or serious intimidation of candidates or voters. In a hopeful sign of the future of the country, the Liberian people participated enthusiastically in the process, demonstrating widespread interest in the election process. Most political party and candidate platforms were only belatedly made available to the electorate. The widespread use of posters, banners and T-shirts was evidence of a highly competitive campaign.

6 The message here is that George Opong Weah is neither a warlord nor part of the old generation of Liberian politicians who brought misery and suffering to their people through civil wars. Weah represents a break from the past and a new generation in politics and should be supported. 


\section{THE ELECTIONS}

The elections were a culmination of intensive preparations by the NEC supported by the UNMIL Electoral Division. The latter was responsible for the logistical backup while 15000 UNMIL soldiers provided security. While polling booths opened late in many precincts, with a surging crowd of voters eager to cast their votes, the voting process was, in most cases, handled by the electoral officials with professionalism and competence. ${ }^{7}$ Some of the features of the elections were:

- the enthusiasm of the electorate on the eve of the elections;

- the large turnout of voters, including the aged, the psychically challenged, the youth and the internally displaced;

- the high level of discipline and patience demonstrated by the electorate while queuing to cast their votes;

- the adequate and unobtrusive security provided at most polling stations;

- the prompt and early arrival of election materials at most polling stations;

- that voting was by secret ballot, which protected the confidentiality and integrity of the voting process;

- that representatives of political parties, candidates and observer missions, local and international, were present at most polling stations and witnessed the voting and counting of votes (Ecowas 13 October 2005).

Fifty domestic and 28 international observer groups monitored the elections - a total of 3773 domestic observers (including the media) and 369 international observers. The overall verdict was that the elections were generally free, fair, transparent, credible and democratic, with the results reflecting the general wishes of the Liberian electorate. In its conclusion Ecowas (13 October 2005) had this to say:

The Ecowas Observer Mission's preliminary conclusion on the $11^{\text {th }}$ October 2005 elections is that the Presidential, Senate and House of Representatives elections were generally peaceful, free, fair, and transparent. The determination and positive spirit of the Liberian people and the National Transitional Government of Liberia to set their country back on the road to democratic rule, peace, stability and progress is highly commended.

The author observed the 11 October and 8 November elections as a member of the coordinating team for the Ecowas Elections Observation Mission to Liberia. 
In the legislative elections (Senate and House of Representatives) parties like COTOL, CDC, NPP, UP, LP, APD, and NDPL had a fairly good showing; however, none of the parties won an overwhelming majority in both parliamentary bodies. But while the legislative elections were settled at the October poll, the presidential election was not. None of the 20 presidential candidates secured the required 50 per cent-plus-one stipulated by the electoral law. The two topmost leading candidates, George Weah and Ellen Johnson-Sirleaf won 28,3 per cent and 19,8 per cent respectively of the valid votes cast. As a result, the two had to face a run-off election.

\section{RUN-OFF PRESIDENTIAL ELECTION, 11 NOVEMBER}

Campaigning for the run-off presidential election commenced shortly after the first-round results were announced. Unlike that in the first round, the political atmosphere in the second round was charged, as the stakes were higher. UNMIL forces, therefore, had to scale up security in order to ensure that there was no violence or threat to peace and order in the country.

While Weah was the candidate to beat in the first round, the balance of political forces shifted considerably in the second. Johnson-Sirleaf went on the offensive and mounted a well-coordinated, organised and strategic campaign. She consulted extensively with key opinion leaders, securing their endorsement, and paid personal visits to defeated presidential, senatorial and House of Representative candidates, carefully choosing those with political capital and goodwill in different communities to support her.

In addition, she took her campaign to the remotest parts of the country, hiring a helicopter to do so. Her political management of the media was phenomenal as her credentials as an international public servant, development expert, and competent administrator were played up. ${ }^{8}$ The issue of education (or the lack of it), which was an advantage to George Weah in the first round, was used against him in the second. The partisan media drew a parallel between Weah and Sergeant Doe, insisting that a poorly educated leader was dangerous to the political health of the country. Swayed by this the professional class and student groups (including the Liberian National Students Union) cast their support in favour of Johnson-Sirleaf and many professionals, both at home and abroad, began to contribute articles to the print media on why Liberians should not entrust their fate to Weah.

8 See, for example, The Analyst 11 November 2005 on 'Qualification vs. Popularity'. 
As John Morlue (2005) corroborates:

From the ground operations to the implementation of political and media strategy, she and her team were on top of the game during the second round. One can document it from the look of the number of press releases and favourable domestic and international coverage. Another way to look how well her campaign was run is on the basis of how well things were coordinated and expensing [sic] of foot soldiers in strategic counties.

On the other hand, Weah's political machinery was weak, uncoordinated and apparently disoriented. Perhaps Weah assumed that, given the results of the first round, he would cruise to victory easily. The alliances he forged proved to be political liabilities rather than assets, with many of the warlords declaring support for him and virtually becoming his spokespeople during the run-off campaign. This development scared many Liberians, negating their previous view that Weah was an 'untainted new breed' politician. The voices of the warlords echoed the horrors of the war in the country.

Weah's media relations during the run-off campaigns were poorly managed - he and his team continuously had problems with journalists, with the PUL alleging that journalists were attacked by CDC members and supporters. Indeed, the PUL was forced to petition the CDC on this issue (The Inquirer 11 November 2005, p 1).

The ethnic card was also played against Weah. Like Samuel Doe he is a Khran, a fact which made it easy for his opponents to conjure up the possibility of a replay of the Doe era in the event of a Weah victory. Images are powerful political weapons.

Weah's campaign team was pre-occupied with rumours and the conspiracy theory that the international community supported Johnson-Sirleaf and wanted to rig the elections in her favour. The result was political inertia and disincentive. A few days before the run-off election Weah raised allegations that the 11 October election had been rigged in favour of Johnson-Sirleaf, and that he had won 62 per cent of the votes cast. This tactic further alienated the team from the electorate.

The result was that Ellen Johnson-Sirleaf won the presidential election.

\section{ECOWAS AND POST-ELECTION DISPUTES}

On three occasions Ecowas, particularly its special mediator, General Abdusalmi Abubakar, had to intervene in the electoral process in order to keep it on course. A few days prior to the 11 October election the Supreme Court, responding to a 
Results of Run-Off Presidential Election of 8 November 2005

\begin{tabular}{|l|l|l|c|}
\hline Party & Presidential candidate & $\begin{array}{l}\text { Vice-presidential } \\
\text { candidate }\end{array}$ & Votes \\
\hline Unity Party & $\begin{array}{l}\text { Ellen } \\
\text { Johnson-Sirleaf }\end{array}$ & $\begin{array}{l}\text { Boakai Joseph } \\
\text { Nyuma }\end{array}$ & $478562(59,4 \%)$ \\
\hline $\begin{array}{l}\text { Congress for } \\
\text { Democratic } \\
\text { Change }\end{array}$ & George Weah & Johnson Rudolph & $327046(40,6 \%)$ \\
\hline & & $\begin{array}{l}\text { Invalid votes } \\
(2,4 \% \text { of the total })\end{array}$ & 20144 \\
\hline & & Total votes & 825716 \\
\hline
\end{tabular}

Source: National Elections Commission of Liberia

suit instituted by three disqualified presidential candidates, ruled that the candidates were qualified and should be allowed to stand. This decision would have created a political stalemate requiring the NEC to postpone the election (New Standard 5 October 2005) because the ballot papers had already been printed. Reprinting them would not only have imposed a heavy financial burden on the NEC, it would also have led to the postponement of the elections and the derailment of the transition timetable. After intervention by Ecowas the three agreed to step down and allow the election to proceed.

The second incident occurred about two days before the run-off presidential election with George Weah's contention that he had won the 11 October election with 62 per cent (New Democrat 4 November 2005). This created the real possibility of conflict between supporters of the two candidates. Abubakar intervened, holding discussions with the candidates.

The third event was in the aftermath of the run-off presidential election when Weah insisted that the elections were not free and fair (National Chronicle 11 November 2005, p 1). Again, Ecowas had to intervene, maintaining that though candidates had the right to disagree with election results their complaints should be voiced through legal channels. After much discussion, Weah decided to accept the results and support the newly elected government. The government, headed by the first female president on the African continent, was sworn in on 16 January 2006. 


\section{CONCLUSION}

The 2005 elections, the most competitive, free, fair, transparent, and credible in the electoral history of Liberia, opened a new chapter in the country's political history. Whereas elections are fast becoming a fading shadow of democracy in many African countries (Adejumobi 2000), in Liberia they constituted a process of national rebirth and democratic renewal. The determination of the Liberian people that the election should succeed was a most decisive factor in ensuring that it did so, as was the commitment of the political elite to the spirit of consociational electoral politics, the logic of political restraint and accommodation by the people, and the intensive preparation of the electoral commission.

Four elements are essential to the consolidation of electoral democracy in Liberia. The first is the nature of governance by the newly elected political leadership, that is, the extent to which they expand rather than contract the political space and make for inclusive political participation in governance. Second, is the extent to which the social dividends of democracy are facilitated by the leadership. This will involve the speedy restoration of electricity, water and good roads and the rehabilitation of war victims. Third, is the continuation of the spirit of consociational politics with restraint and responsible opposition. Fourth, is the continued support by the international community for post-conflict transition and reconstruction in the country.

The political process in Liberia remains fragile, and possibly reversible, and requires the active support of the international partners to consolidate it and make it grow. The newly established United Nations Peace Building Commission may consider Liberia a test case in support of post-conflict reconstruction and development by the United Nations. However, ultimately, the responsibility for democracy, good governance and development in Liberia lies primarily with Liberians themselves. 
Adebajo, A. 1989. Building Peace in West Africa: Liberia, Sierra Leone and Guinea Bissau. Boulder, Colorado: Lynne Rienner Publishers.

Adejumobi, S. 2000. 'Elections in Africa: A Fading Shadow of Democracy? International Political Science Review 21(1).

2004. 'Conflict and Peace Building in West Africa: The Role of the Civil Society and the African Union'. Conflict, Security and Development 4(1).

Alao, A, J Mackinlay \& F Olonisakin. 1999. Peace Keepers, Politicians and Warlords: The Liberian Peace Process. Tokyo: United Nations University Press. Analyst, The 6(190). 17 May 2005.

- 7(59). 7 November 2005. 7(61). 11 November 2005.

Aning, K E. 1997. The International Dimensions of Internal Conflict: The Case of Liberia and West Africa. Centre for Development Research, (CDR), Copenhagen: Working Paper 97, June.

Conteh, A, J Guannu, H Badio \& K Bruce. 1999. 'Liberia'. In A Adedeji (ed). Comprehending and Mastering African Conflicts: The Search for Sustainable Peace and Good Governance. London: Zed Books.

Carter Center. 2005a. Liberia Election Watch 1, 4 August.

- 2005b. Liberia Election Watch 2, 12 August.

- 2005c. Liberia Election Watch 4, 16 September.

- 2005d. Liberia Election Watch 5, 26 September.

Daily Observer 10(98). Monrovia, 11 November 2005.

Dukule, A. 2005. 'Elections 2005: Another Debate'. The Perspective, 17 September http: / / www.perspective.org/articles / 0917200503.html

Ecowas Observer Mission to the 11 October 2005 Elections in Liberia. Preliminary Statement on the Elections, 13 October (Monrovia).

Ellis, S. 1995. 'Liberia: 1989-1994: A Study in Ethnic and Spiritual Violence'. African Affairs 94 (375).

—. 1998. 'Liberia's Warlord Insurgency'. In C Clapham (ed). African Guerrillas. Oxford, Kampala, Bloomington and Indianapolis: James Currey, Fountain Publishers, and Indiana University Press.

European Union Election Observation Mission in Liberia. 2005. Statement of Preliminary Findings and Conclusions on the October 112005 Elections', 13 October (Press Release).

Gberie, L. 2005. 'Liberia's War and Peace Process: A Historical Overview'. In F Aboagye \& MS Bah. A Tortuous Road to Peace: The Dynamics of Regional, UN and International Humanitarian Interventions in Liberia. Pretoria: Institute for Security Studies. 
Gershoni, Y. 1997. 'War without End and End to a War: The Prolonged Wars in Liberia and Sierra Leone'. African Studies Review 40(55).

Hoffman, D. 2004. 'The Civilian Target in Sierra Leone and Liberia: Political Power, Military Strategy and Humanitarian Intervention'. African Affairs 103(215). Inquirer, The 14(6). Monrovia, 14 September 2005. 14(8). Monrovia, 11 November 2005.

Jarret, M B. 1996. 'Civil War in Liberia, 1989-1996: A Manipulation of Chaos?' Master's Dissertation in Area Studies, Africa, School of Oriental and African Studies, London.

Liberian Comprehensive Peace Agreement (CPA), August 18 2003. Accra, Ghana. Liberia, Political Parties Code of Conduct, 2005. Monrovia.

Massing, M. 1990. ‘Best Friends'. Africa Report, September-October.

Mamdani, M. 1996. Citizen and Subjects. Princeton, New Jersey: University of Princeton Press.

Morlue, J. 2005. 'Handicapping the Liberian Elections: A Post-Elections

Analysis', 11 September http:/ / www.frontpageafrica.com/

RunScript.asp?page $=26 \&$ Article_ID $=397 \& N W S=$ NWS\&ap

$=$ NewsDetail.asp $\& \mathrm{p}=\mathrm{ASP} \backslash \sim \operatorname{Pg} 26$.asp

Mgbeoji, I. 2003. Collective Security: The Liberian Crisis, Unilateralism, and Global Order. Vancouver: University of British Columbia Press.

National Chronicle 10(105). 11 November 2005.

New Democrat 12(88). Monrovia, 4 November 2005.

New Standard 1(33). Monrovia, 5 October 2005.

Osaghae, E. 1996. Ethnicity, Class and the Struggle for State Power in Liberia. CODESRIA Monograph Series. Dakar: CODESRIA.

Pham, J. 2004. Portrait of a Failed State. Oregon: Reed Publishers.

Scott, R. 2005. Moving from Impunity to Accountability in Post-War Liberia: Possibilities, Caution and Challenges. Working Paper, Expresso Preprint Series, University of Berkeley Electronic Press http / / law.bepress.com/expresso/eps/ 606.

Sesay, A. 1992. 'Historical Background to the Liberian Crisis'. In M A Vogt (ed). The Liberian Crisis and ECOMOG: A Bold Attempt at Regional Peace Keeping. Lagos: Gabumo Publishing Company.

The New Electoral Laws of Liberia, 4 October 1986.

The Ballot 1(3). 2005. Monrovia: National Elections Commission (NEC), August. Zimmerman, R. 1993. Dollars, Diplomacy and Dependency: Dilemmas of U.S. Economic Aid. Boulder: Lynne Rienner Publishers. 